\title{
12 Marine fisheries and aquaculture in the Arctic
}

\author{
Catherine Chambers, Theresa Henke, \\ Brad Barr, David Cook, Barry Costa Pierce, \\ Niels Einarsson, Brooks Kaiser, \\ Ögmundur Knútsson, Matthias Kokorsch, \\ \& Trent Sutton
}

\section{Introduction}

Arctic peoples and economies have long been linked with reliance upon living marine resources. Fisheries livelihoods center on both capture fisheries and its related industries (fish processing, gear manufacturing, harbor operations, etc.), and subsistence fisheries that contribute to local mixed economies (Vilhjálmsson et al., 2005; SADA Report, 2014; Zeller, Booth, Pakhomov, Swartz, \& Pauly, 2011). The rich, productive waters of the Arctic supply over $10 \%$ of the world's marine fish catches (CAFF, 2013) and delete for culturally important traditional fisheries to the over 40 ethnic groups of the Arctic (Fondahl, Filippova, \& Mack, 2015). Further, although aquaculture production for all of the Arctic hasn't changed much since 2014, it remains an important economic sector and has opportunities for growth (FAO, 2020). The Arctic marine socio-ecological ecosystem is experiencing continuous, rapid change, including shifts in the range of fisheries, decreasing sea ice coverage, increased risk of pollution, and varying forms of economic development and governance changes that can have both positive and negative impacts (Lam, Cheung, \& Sumaila, 2014; Burgass et al., 2019; Kaiser, Pahl, \& Horbel, 2018). As interest in the Arctic marine space increases, it is ever more important for research and policy to address specific challenges at local, regional, national, Arctic, and global levels. For example, as areas of the Arctic are becoming more and more accessible due to melting sea ice, there is increasing interest in developing new fisheries in the northern seas (Lam et al., 2014). Even though these fisheries would generate a positive economic benefit for the Arctic, developing the area bears a potential ecological risk (Lam et al., 2014). Another example is that of access to local fisheries, whether commercial or subsistence, where access rights to specific resources are governed without the interests of small-scale actors in mind (Briant, 2018; Chambers, Einarsson, \& Karlsdóttir, 2020). This creates systems of inequity that can impact the well-being and selfactualisation goals of sustainable development. While fisheries and aquaculture can provide continued and perhaps expanded opportunities for

DOI: $10.4324 / 9781003172406-12$ 
renewable Arctic economies, barriers and uncertainties related to climate change, socio-economic change, environmental impacts, and institutional and political obstacles can create challenges.

Information reviewed in this chapter will provide background information and identify opportunities and constraints related to fisheries and aquaculture to increase our understanding of renewable economies in the Arctic. The specific objective of this chapter is to use the best available data to contribute to scholarship, policy and future development by identifying opportunities and threats for current and fisheries and aquaculture activities in the Arctic. The chapter is organised as follows. Section 2 reviews the best available knowledge related to fisheries and aquaculture in the Arctic from an interdisciplinary perspective, including the impacts of climate change. To narrow the scope, this chapter does not cover other living marine resources such as marine mammals or seabirds. Next, Section 3 identifies opportunities and threats related to renewable economies based on fisheries and aquaculture in the Arctic related to governance challenges. Section 4 then identifies knowledge gaps relevant for the research community by highlighting areas for future research under the framework of the United Nation Sustainable Development Goals (UN SDGs). The chapter concludes by offering key considerations for Arctic communities and decision-makers interested in renewable economies that include fisheries and aquaculture.

\section{Background}

There is a wealth of scholarship on Arctic fisheries and aquaculture (see, for example, Zeller et al., 2011; Kourantidou et al., 2021). Rather than extensively reviewing the literature, this section highlights the current state of knowledge of Arctic marine socio-ecological systems, which will then be used to highlight specific focus areas under the SDGs in Section 3. The PAME (Protection of the Arctic Marine Ecosystems) Working Group of the Arctic Council identifies 18 LME's (Large Marine Ecosystems) of the Arctic. Not all waters of Arctic nations are in the 18 Arctic LME's, and non-Arctic nations may fish in Arctic waters. Therefore, the information presented below denotes the best available data based on either Arctic LME's, sub-Arctic waters, or Arctic nations.

\section{Fisheries}

\section{Subsistence fisheries}

The Arctic has a long history of Indigenous fisheries, heavily relying on marine resources such as fish and mammals (AHDR, 2004; CAFF, 2013). Various traditionally harvested food sources are an important part of the diet in Arctic Indigenous communities such as in the Canadian and Alaskan Arctic with whitefishes (Coregonis sp.), salmon (Onchorchynchus sp.), char (S. alpinus) and trout (Salvelinus sp.) representing the most frequently consumed fish species (Kuhnlein \& Receveur, 2007). In Greenland, the 
population largely consists of Indigenous inhabitants, making up approximately 90\% in 2019 (Statistics Greenland, 2019). Up until today, small-scale commercial fisheries and hunting are an important economic aspect in the eastern, southern, and northern parts of Greenland (Pálsson, n.d.).

\section{Commercial fisheries and processing}

According to the United Nations Food and Agriculture Organization (FAO), the Arctic can be divided into the Fisheries Statistical Area 18 and 27 (Zeller et al., 2011). Area 18 can be subdivided into the 8 Large Marine Ecosystems (LME) of the Kara Sea, Laptev Sea, East Siberian Sea, Chukchi Sea, Beaufort Sea, Arctic Archipelago, Baffin Bay, and Arctic Ocean (Zeller et al., 2011). Using the PAME designation of the 18 Arctic LME's, the commercial fishery catch in 2014 is outlined below in Table 12.1, using Sea Around Us data (seaaroundus.org).

Table 12.1 Commercial fishery catch in Arctic large marine ecosystems (LME) in 2014

\begin{tabular}{|c|c|}
\hline LME & 2014 catch (1000 tonnes) \\
\hline 1-Faroe Plateau & 413.27 \\
\hline 2-Iceland Shelf and Sea & 914.71 \\
\hline 3-Greenland Sea-East Greenland & 172.97 \\
\hline 4-Norwegian Sea & 1108.23 \\
\hline 5-Barents Sea & 1355.5 \\
\hline 6-Kara Sea & 1.64 \\
\hline 7-Laptev Sea & 2.17 \\
\hline 8-East Siberian Sea & 1.18 \\
\hline 9-East Bering Sea & 1001.59 \\
\hline 10-Aleutian Islands & 725.73 \\
\hline 11-West Bering Sea & 804.75 \\
\hline 12-Northern Bering-Chukchi Sea & 377.32 \\
\hline 13-Central Arctic Ocean & 0 \\
\hline 14-Beaufort Sea & .24 \\
\hline 15-Canadian High Arctic-North Greenland & 0 \\
\hline 16-Canadian Eastern Arctic-West Greenland & 194.99 \\
\hline 17-Hudson Bay Complex & 1.47 \\
\hline 18-Labrador-Newfoundland & 487.15 \\
\hline
\end{tabular}


While some of the most productive fishing grounds are located in the sub-Arctic region, such as the Barents and Bering Sea, with 633 fish species occurring of which 58 are considered commercial, the Arctic basin is comparably deserted with only 3 commercial species out of 63 (Meltofte, 2013; SADA report, 2014). These productive fisheries are usually characterised by only one or two species, with the Bering Sea being dominated by Pollock and the Barents Sea by a cod-capelin system (SADA report, 2014).

The Russian area of the Arctic consists of the Kara Sea, the Laptev Sea and the East Siberian Sea as well as the Chukchi Sea, which is also bordered by the United States (Zeller et al., 2011). In accordance to the overall low fishery production of the Arctic waters, the Russian Arctic areas sustain a low number of fish species (Pauly and Swartz, 2007; Zeller et al., 2011). There were significant increases in the population of Siberia during the Soviet regime, and the current expanding industrialisation of the Russian Arctic between the 1960s and today has further expanded the population of the region. The implications of potentially increasing capture fisheries targeting such limited fish populations in adjacent Arctic waters is uncertain, but reported estimates of current fisheries production from this region may not accurately reflect its potential in this regard (Zeller et al., 2011).

Commercial fishing in the Kara Sea is dominated by six species of white fish, making up about $80 \%$ of the landings (Zeller et al., 2011). In the Laptev and East Siberian Seas, there are no commercial fisheries being operated and instead just small-scale fisheries (Newell, 2004). The East Siberian Sea does have populations of pink salmon (Oncorhynchus gorbuscha) and Dolly Varden (Salvelinus malma) that could sustain commercial harvesting on the grounds of size, but these populations are facing the risk of overfishing (Newell, 2004). In the area of the Chukchi Sea, the human population has been steadily decreasing with about 1,000 people remaining in coastal areas where they rely heavily on marine food sources (Newell, 2004; Zeller et al., 2011).

In 2009, under the United States Magnuson-Stevens Fishery Conservation and Management Act, an Arctic management area was implemented north of Alaska, reaching from the Seward Peninsula to the Canadian border and therefore covering parts of the Chukchi and Beaufort Sea (NPFMC, n.d.). In this area, all commercial fishing for finfish, crustaceans, and other animals except for marine mammals and birds, is prohibited to protect the sensitive ecosystem from potentially destructive fishing activities (NPFMC, n.d.). However, fisheries in the sub-Arctic waters of Alaska accounted for $2.67 \mathrm{M}$ tons of catch or $\$ 1.872$ billion 2010 USD in 2014 (seaaroundus.org) and are a vital economic activity in coastal communities.

\section{Aquaculture}

In the Arctic, harvesting fish from aquaculture is limited, however, there is room for growth in the sector for mainly finfish aquaculture (SADA report, 2014; Barbier \& Burgess, 2017). There is also a small but growing niche 
production of seaweeds and shellfish (Allison, Badjeck, \& Meinhold, 2011). Norway, by far, dominates aquaculture production in the Arctic, mainly through salmon farms, followed by the USA and Canada (AP, 2012; SADA report, 2014). Norway's production of Atlantic salmon (Salmo salar) was valued at 2.2 billion EUR in 2010 (Norwegian Directorate of Fisheries, 2020). In Alaska, finfish aquaculture is prohibited (ADF\&G, n.d.) but the aquaculture sector produces shellfish, such as Pacific oyster (Magallana gigas) and blue mussels (Mytilus trossulus), and kelp, which generated 1.53 million USD in 2017 (Pring-Ham, 2018). Meanwhile in Canada, as in Alaska, no measurable aquaculture currently takes place in Arctic waters, but in the sub-Arctic Pacific waters of British Columbia, 88,834 tons of finfish were produced in 2018, generating a value of 791 million CAD (Fisheries and Oceans Canada, 2020). In the Canadian Atlantic, Newfoundland, New Brunswick, and Newfoundland combine to produce 51,634 tons in 2018 for a value of 480 million CAD (Fisheries and Oceans Canada, 2020). Salmon pen aquaculture is rapidly expanding in Iceland, with backing from Norwegian companies. In 2018, 19,000 tons were produced, consisting mostly of salmon and Arctic char for an export value of 13.1 billion ISK in 2018 (Statistics Iceland, 2020). In Russia, there are cultivation rights for 30 salmon and trout sites in the Murmansk and Karelia regions, with the strategic goal of increasing by $16-18$ farms in 2025 to produce up to $25-30,000$ tons of salmonids. This growth coincides with the steady demand for and consumption of salmonids in Russia during the last decade along with the identification of aquaculture as a top priority in the agri-food section by the country's authorities.

\section{Impacts of climate change}

Based on model predictions, the effects of climate change will be most acute in the Arctic, with sea surface temperatures expected to rise more than in temperate latitudes (Team, Pachauri, \& Meyer, 2014). The rate of climate change is considered to be two times faster in the Arctic than in other regions, and it is projected that the rate of ocean warming might be up to seven times faster than projected changes in terrestrial landscapes (Burrows et al., 2011). As an example, with $1.5^{\circ} \mathrm{C}$ of ocean warming, mobile species, such as plankton and fishes, might be driven to relocate at higher latitudes. Those species that cannot move, such as kelps and corals, would undergo high mortality, causing damage to dependent ecosystems (Hoegh-Guldberg et al., 2018). With either the mortality of sessile specie or the range expansion of mobile species, the marine ecosystem complexes may experience great change. In the Arctic, change has already shown some impacts on the environment, both the abiotic and biotic components (Wassmann et al., 2011; Hoegh-Guldberg et al., 2018, AMAP, 2018). Other chemical changes occur due to the absorption of anthropogenic carbon dioxide have already been observed in the Beaufort Sea and in Alaska's coastal waters (Sumaila, 2015), resulting in ocean acidification that can affect the growth and development 
of organisms that build shells. This in turn impacts a wide range of marine species further down the food web that depend on shelled organisms for food (AMAP, 2018). However, documenting particular changes is not easy due to a lack of reliable baseline data, which is needed for a comparison to the current situation (Wassmann et al., 2011).

Expected changes in the Arctic include more than just warming air and water temperatures; for example, the observed mean annual spatial extent of sea ice has been decreasing 3.5-4.1\% per decade and precipitation is expected to increase between 30 and 50\% (Team, Pachauri, \& Meyer, 2014). The reduction in the duration of shore-fast sea ice will likely yield greater coastal erosion due to more impactful winter storms, with coastlines in many locations of the Beaufort Sea expected to undergo high rates of erosion (Gibbs \& Richmond, 2015; Jones et al., 2009). Increased coastal erosion in the central Beaufort Sea has amplified the suspension of sediment load, thereby reducing benthic and water column primary production (Bonsell \& Dunton, 2018). Such large-scale changes in environmental conditions in the nearshore region of the Arctic have significant implications for the ecological responses of local fishes as well as other marine organisms.

\section{Physical impacts on marine ecosystems}

All fishes are impacted by variability in their surrounding environment (Fechhelm, Fitzgerald, Bryan, \& Gallaway, 1993). Water temperature and salinity are perhaps most influential, and deviations from "normal" conditions can lead to significant energetic costs through increased temperature regulation, metabolism, and osmoregulation (Bœuf \& Payan, 2001; Edsall, 1999). Fish species that are forced to inhabit environments with conditions outside their optimal requirements can experience reductions in growth and recruitment and/or higher mortality (Arnesen, Jørgensen, \& Jobling, 1993; Dutil, Lambert, \& Boucher, 1997). To optimise growth and survival, fish may seek environments which provide conditions to optimise growth and survival (Monaghan, 2008); to locate such conditions may include shifts in geographic distribution (Hansen \& Closs, 2009; Křivan, 2003). As a result, the magnitude, duration, and variability of environmental factors all play a significant role in determining the fish species composition, abundance, and rate-dynamic parameters, especially in dynamic environments such as the Arctic.

Despite the variable environment, nearshore Arctic waters support a variety of fishes. Whitefishes, such as Arctic Cisco Coregonus autumnalis, Broad Whitefish C. nasus, Least Cisco C. sardinella, and Humpback Whitefish $C$. pidschian, are amphidromous species that are tolerant of moderate levels of salinity and often undergo long-range migrations (de March, 1989; Fechhelm et al., 1993). For example, Arctic Cisco in Alaskan waters of the Beaufort Sea originate in the Mackenzie River, Northwest Territories, Canada, and are transported as juveniles $>500 \mathrm{~km}$ along the shore via 
easterly wind-driven surface currents (Fechhelm \& Fissel, 1988; Fechhelm \& Griffiths, 1990). However, other coregonids (for example, Broad Whitefish, Humpback Whitefish, and Least Cisco) spawn in rivers throughout northern Alaska and Canada (Craig, 1984, Craig, 1989; Fechhelm, Bryan, \& Griffiths, 1994). Regardless of species, juvenile whitefishes spend the short growing season (late June into September) feeding in coastal estuaries and deltas of the Beaufort Sea and overwinter in freshwater pools or upwelling areas in coastal tributaries (Craig, Griffiths, Haldorson, \& McElderry, 1985; Fechhelm, Martin, \& Gallaway, 1999; Seigle \& Gottschalk, 2013). The gadids Arctic Cod (Boreogadus saida) and Saffron Cod (Eliginis gracilis) are also ecologically important and support the Arctic marine ecosystem with their high abundance and energetic content (Elliott \& Gaston, 2008; Harter, Elliott, Divoky, \& Davoren, 2013; Thorsteinson \& Love, 2016). These species serve as a key link between lower trophic levels (for example, calanoid copepods and amphipods) and higher trophic organisms (for example, seabirds and marine mammals; Harter et al., 2013). Pacific salmon Oncorhynchus spp. have been documented in the Arctic at increasing frequency in recent years, with a natal population in the Mackenzie River in Canada and potentially other rivers of the central Beaufort Sea in Alaska (Gatt, Hamman, Priest, \& Sutton, 2019; Irvine, Macdonald, \& Brown, 2009).

\section{Impacts to coastal communities: Food security, economic opportunity, and local infrastructure}

In addition to their key role in the ecology and food-web structure of coastal marine ecosystems, nearshore fishes also provide important subsistence food resource for local Indigenous communities (Fechhelm, Streever, \& Gallaway, 2007; Thorsteinson \& Love, 2016). As a consequence, the effects of climate change could significantly impact fishing activities of Indigenous peoples (Galappaththi, Ford, Bennett, \& Berkes, 2019). As higher levels of acidity are already documented for the Beaufort Sea (Zhang, YamamotoKawai, \& Williams, 2020) and Alaska's waters (Monacci, Cross, Hurst, Long, \& Rossin, 2019), Indigenous communities might eventually not have enough nearshore marine resources available to harvest as fish stocks will be decreasing due to lower prey availability (Sumaila, 2015). As a result, climate change has the potential to disrupt food security for humans. While there are no commercial fisheries in federal waters of Arctic Alaska, subsistence fisheries in nearshore areas are important socio-cultural and nutritional contributions to local Inupiaq communities (Fechhelm et al., 2007; NPFMC, 2009). Communities along the Chukchi and Beaufort Sea coastline, such as Utqiagivik, Nuiqsut and Kaktovik, are dependent on the subsistence harvest of marine organisms, including abundant whitefishes found in the river deltas and nearshore coastal waters (Craig, 1987; Braund et al., 2012). Although the economic impact of these fisheries is limited, ecological changes in the Arctic would have substantial ramifications for both 
food-web structure and dynamics as well as human communities (Moerlein $\&$ Carothers, 2012). As a result, the importance of Arctic fishes to coastal communities necessitates the examination of potential effects of climate change prior to understanding how ecosystems and food security may be impacted in the future (Reist et al., 2006).

There is also uncertainty involved in projecting fisheries catches for commercial stocks under climate change (Cheung et al., 2016) and how the fishing industry might change. While it can be assumed that fisheries-dependent communities could adapt to fluctuating fish stocks or might even profit in the short term, their overall adaptive capacity is limited due to the threatened infrastructure and other socio-economic factors (Alvarez, Yumashev, $\&$ Whiteman, 2020; Ford, McDowell, \& Pearce, 2015). The adaptive capacity of Arctic fishing communities can be defined as the ability to cope with external stresses, such as climate change, and the ability to modify or change (Kokorsch \& Benediksson, 2018). It is an integral part of community resilience which describes " $[. .$.$] the ability of a community to cope and$ adjust to stresses caused by social, political, and environmental change and to engage community resources to overcome adversity and take advantage of opportunities in response to change" (Amundsen, 2012, p. 1). However, the adaptive capacity and community resources are somewhat limited and dependent on economic factors, decision making power and resource access that are usually not part of the local agency (Landauer \& Juhola, 2019; Ford et al., 2015). Relevant locational factors include infrastructures for the communities in general and the fishing industry in particular. Especially fisheries dependent communities with a monotonous local or regional economy are predicted to face difficulties due to climate change. Community infrastructure, local agency and a diversified economy are, however, key parameters for resilience building and the preparedness for transformative shocks (drastic shifts or sudden changes) or structural changes (slow and gradual processes) (Kokorsch, 2018).

Arctic coastal communities are not only dependent on the infrastructure at the shoreline, but also the hinterland and transportation systems onshore are of relevance. Thus, climate change related threats to renewable fisheries economies are not limited to melting sea ice and rising sea levels, but include coastal erosion, thawing permafrost, extensive precipitation, flooding and severe weather (Landauer \& Juhola, 2019; Moon et al., 2019; Melvin et al., 2017). Hence, some communities, for example in coastal Nunavut or Alaska, will face multiple threats and socio-economic burdens (Alvarez et al., 2020; Melvin et al., 2017; Walker \& Peirce, 2015). It can be expected that climate change will lead to significantly higher costs for maintenance, restructuring or new construction of critical infrastructure (Larsen et al., 2008; Pahl \& Kaiser, 2018; Streletskiy, Suter, Shiklomanov, Porfiriev, \& Eliseev, 2019; Suter, Streletskiy, \& Shiklomanov, 2019). While rising costs for infrastructure are not a problem per se, in the Arctic it hits communities and industries that are commonly investment-intensive and 
face small profit margins (Stephen, 2018; Suter et al., 2019). Recommended proactive investments in adaptation and infrastructure preparedness are subject to debate regarding their financing and responsibility (Landauer \& Juhola, 2019; Melvin et al., 2017). From this perspective, it is debatable to what extent renewable economies can be sustained, in a setting in which critical infrastructure is vulnerable. In other terms, the economic fundamentals (literally and figuratively) might not be renewable but need to be constantly renewed.

Apart from the impact on infrastructure and local economies, several socio-cultural and demographic consequences for coastal communities due to climate change can be identified: cultural heritage loss, health disparities and worsening food and water security (Alvarez et al., 2020; Fritz, Vonk, \&, Lantuit, 2017; Irrgang, Lantuit, Gordon, Piskor, \& Manson, 2019; Stephen, 2018). The combination of these factors might lead to intensified out-migration or the relocation of some communities, thereby impacting the workforce for economic activities. The attractiveness of the fishing sector (capture fisheries and subsistence fisheries) on and offshore will be negatively affected by the threats outlined above; fisheries are a business sector that can be characterised as unstable and climate change is an additional hindrance for new entrants to the industry in the long run. Aquaculture might be an alternative business strategy for Arctic coastal communities and an opportunity to respond to the changes and threats.

\section{Impacts to aquaculture}

Aquaculture is likely not as affected by climate driven change in the environment as the commercial fisheries, since location, population density and resource availability are controlled factors (SADA report, 2014). Significant environmental changes might change the distribution of the aquaculture industry throughout the Arctic (SADA report, 2014), but overall aquaculture in the Arctic will likely see positive effects from warming water temperatures (Hermansen \& Troell, 2012). For example, the climateinduced temperature rise on the Norwegian coasts is likely to range between 0.5 and $2.5^{\circ} \mathrm{C}$ and will play out differently during different seasons. Despite large uncertainties, and just a few detailed studies that specifically target climate change impacts on Arctic aquaculture, the direct effects of temperature change on the aquaculture industry can be modelled with fairly good accuracy, including effects on fish growth and impacts on the whole industry. Present optimal conditions for open sea cage salmon farming in Norway lie between 62 and $64^{\circ}$ North latitude. Further south, summer temperatures are higher than optimum, and further north, temperatures are too low throughout the year. Increased sea temperatures will generally move this optimal zone further north. For fish farms in colder locations than optimal, production can increase with $11-15 \%$ per degree increase in temperature (Lorentzen, 2008). For farms at optimum or higher temperatures, 
production will decrease. Salmon farms in the Arctic generally experience lower than optimum temperatures and will therefore likely experience improved productivity. Species like cod and halibut have narrower temperature ranges and should respond in a similar way (Troell et al 2017). As a buffer against uncertain climatic impacts of sea-pen aquaculture, employing recirculating aquaculture system (RAS) technologies is seen as a means of reducing exposure to climatic extremes. The RAS are expensive in terms of both capital and operational costs and require high levels of technical expertise (Murray, Bostock, \& Fletcher, 2014). The long-term reliability of RAS still needs to be demonstrated. Aquaponics, the production of fish and plants in an integrated system, is proposed as a means of producing food in areas where freshwater is limited (Somerville, Cohen, Pantanella, Stankus, \& Lovatelli, 2014).

\section{Opportunities and threats related to governance systems}

The management of the Arctic areas of those nations adjacent to the Arctic Circle lies within each country's national governance (Burgass et al., 2019). Under the 1982 United Nations Convention on the Law of the Sea (UNCLOS), each country is obliged to prevent overfishing by national fisheries within the EEZ (Pinsky et al., 2017. However, some issues reach beyond just one jurisdiction and therefore require nations to work together and develop joint management strategies (Pinsky et al, 2017; Van Pelt, Huntington, Romanenko, \& Mueter, 2017). Therefore creating new, more legally binding cooperative fisheries governance mechanisms and strengthening existing agreements, has been identified as a pressing need (Molenaar, 2012; Molenaar, 2013).

The Arctic Council was created to provide a forum for enhancing and expanding international collaboration in the Arctic, but any focus on fostering such collaboration with regard to sustainably managing fisheries in this region has largely been "off the table" (Molenaar, 2013). As reported by Schatz et al. (2020), "the Arctic Council decided in 2007 that fisheries issues should be considered 'within the context of existing mechanisms.", However, Molenaar (2012) has observed that "there is no juridical obstacle" for the Arctic Council to take a more active role, and it has engaged in some broader international fishery management-related discussions through its standing committees. While the Arctic Council has not "explicitly reversed" its formal position with regard to governance and international coordination and management of fisheries in the region, it could, and perhaps should, take a more active role (Molenaar, 2013).

As extensively reviewed and summarised by Molenaar (2012, 2013), the existing governance framework for fisheries in the Arctic encompasses global, regional and bilateral fora and instruments, as well as limited Indigenous co-management arrangements (Ayles, Porta, \& McV Clarke, 2016). However, all of these arrangements, instruments and fora are 
constrained by lack of sufficient data, inadequate domestic regulation, gaps in important Arctic Coastal State fora and instruments, and gaps in high seas coverage with Regional Fishery Management Organizations (RFMOs) and other arrangements (Molenaar, 2013). This last identified shortcoming was more recently addressed in 2018 by the signing and ratification of the "Agreement to Prevent Unregulated High Seas Fisheries in the Central Arctic Ocean" (2020). This agreement was signed in Ilulissat, Greenland, by the five Arctic states of Norway, Denmark (for the Faroe Islands and Greenland), Canada, the United States, and Russia as well as by Iceland, Japan, Korea, and China (European Commission, 2018; Harvey, 2018; NOAA Fisheries, 2018). Such broader participation in creating new, and enhancing existing, Arctic fisheries management instruments and agreements continues to be a significant challenge and needs to be actively pursued (Molenaar, 2012) as it was for this agreement.

This CAOF agreement has been represented as the first preventive, international agreement of such magnitude (Harvey, 2018; Rayfuse, 2018; NOAA Fisheries, 2018). Currently there is no fishing activity actively occurring in the $\mathrm{CAO}$, but exploratory fisheries have been conducted in that area in the past (Harvey, 2018). The agreement provides for some limited continuation of this exploratory fishing activity under requirements to be developed within three years of the agreement's ratification. For a period of 16 years following ratification, commercial fishing is limited, "pursuant to conservation and management measures for the sustainable management of fish stocks adopted by one or more regional or sub-regional fisheries management organizations or arrangements" (Article 3,1a), and any "conservation and management measured that may be established" by the parties (Article 3,1b). Encompassing an area of approximately 2.8 million $\mathrm{km}^{2}$, commercial fishing will only be allowed after this 16-year period if international management strategies are developed and implemented to manage such fisheries (NOAA Fisheries, 2018). Furthermore, the agreement also requires (Article 4,2) the establishment of a "Joint Program of Scientific Research and Monitoring" to better understand the ecosystem and potential impacts of fisheries as well as create a baseline needed to document future development (Harvey, 2018; NOAA Fisheries, 2018). This joint program also explicitly includes the integration of "Indigenous and local knowledge" (Article 4,4). By largely prohibiting commercial fishing activity for the period the agreement is in force and effect, not only are fish populations present in the CAO protected from overexploitation, but potential pollution and damage caused by the vessels will be very limited (Harvey, 2018). However, before the agreement comes into force, all nations that have signed the agreement must ratify their commitment which, as of August 2019, has only been done by Canada, the EU, Russia, and the United States (US Dept of State, 2020). Some analyses of the agreement have predicted that closing the high seas could eventually benefit coastal fisheries as the high seas would become recovery areas from which a spill-over effect 
could replenish harvested fish stocks in coastal areas (Sumaila et al., 2015). However, the agreement has also been the subject of some criticism. Schatz et al. (2019) provides a comprehensive and exhaustive legal analysis of the agreement that identifies potential conflicts and ambiguities, concluding that "the success of the newly concluded CAOF Agreement cannot be assessed from a purely legal standpoint, but largely depends on the political will of its parties to implement the rights and obligations codified therein in an effective, lawful and legitimate manner."

Arctic Coastal States and non-Arctic countries have participated in both unilateral National actions to address fishery management in their Arctic waters and have engaged in international collaborations. The United States was the first nation to set an example on protecting their Arctic waters by adopting, in 2009, a Fishery Management Plan for their Arctic management area that bans commercial fishing activity (NPFMC, n.d.). China has not only shown interest in the development of the Arctic but has been involved in Arctic politics over the past decades, such as its involvement as an observer in the Arctic Council (Pan and Huntington, 2016; Østhagen, 2019, Kuo, 2019). Particularly on Svalbard, China has established considerable infrastructure to conduct research on natural science as well as on opportunities to utilise Arctic resources to strengthen further the relationship to Arctic states (Pan \& Huntington, 2016; Østhagen, 2019; Kuo, 2019). Besides their interest in possible Arctic sea routes, there are incentives for involvement in potential Arctic fisheries to ensure enough resources for China's growing population, recognising that local fish stocks are in decline (Østhagen, 2019, Kuo, 2019). The European Union lacks direct access to the Arctic Ocean, but the EU states of Finland, Sweden, and Denmark are geographically positioned close to the Arctic (Østhagen, 2019). Interest in being involved in the policy of developing the Arctic has been expressed by the EU (Østhagen, 2019). The EU's Arctic Policy as well as their Ocean Governance policy highlights various goals, including sound stewardship of the high seas, developing a responsible strategy to access the Arctic's resources, and at the same time respecting the rights of Indigenous communities in the Arctic (European Commission, 2018).

While it is clear that progress is being made towards creating and implementing a governance framework for fisheries in the Arctic, the challenges are significant. Many countries are involved that often have conflicting interests. It could be argued that the power, and much of the responsibility, lies with the Arctic Coastal States in achieving this goal, but many other countries have interests in the future of Arctic fisheries, and their perspectives must be heard. Most importantly, the Indigenous peoples of the North are very much affected by the outcome of these deliberations over fisheries resource allocations and conservation, and need to be at the table and share equally in the decision making. Many hard choices and trade-offs need to be made as this new and hopefully integrated and comprehensive 
fisheries governance framework is crafted. As Jensen and Rottem (2010) have observed, "The Arctic region does not suffer under a state of virtual anarchy, despite outward appearances."

\section{The future of aquaculture in the Arctic}

Recent international policy directives from the UN recommend replacing meat with seafood to limit global temperature rise to 1.5 degrees $\mathrm{C}$, and that increasing food production in the ocean through aquaculture is a key strategy in reaching the climate goal set in the Paris Agreement. Other directives for growth, such as the EU Blue Economy Report, identify worldwide opportunities for aquaculture production, and Arctic nations are among those with strong potential due to the environmental changes discussed above. However, governance of aquaculture in the Arctic is in constant flux and this presents a challenge for communities planning for growth.

In the United States, the Advancing the Quality and Understanding of American Aquaculture Act was introduced in the US Senate in 2018 (S $3138-115^{\text {th }}$ Congress) and the United States House of Representatives (HR6966 - $115^{\text {th }}$ Congress) to encourage aquaculture to meet the global demand for seafood (Resneck, 2018; Bittenbender, 2019). As this new bill could impact the ban of finfish aquaculture in Alaska, the United States Rep. Don Young responded by filing the Keep Fin Fish Free Act to ensure the health of wild fish stocks (Bittenbender, 2019). While the 2018 bills did not progress, a 2020 version was introduced to the United States House of Representatives in March and is progressing through Committee reviews (HR $6191-116^{\text {th }}$ Congress). More recently, the United States president has signed an executive order intended to expand United States aquaculture production rapidly due to pressures from the COVID-19 pandemic to increase domestic food production and reduce foreign trade (EO 13921, 85 Fed. Reg. 28,417 (May 12, 2020)).

In Russia, there is a clear example of how the growth of aquaculture is linked with political decisions that are not easily reversed. Sanctions introduced in August 2014 that prohibited imports of trout and salmon to Russia from Norway, the EU, United States, Canada, and Australia meant that Russian companies expanded to replace the near 200,000 tons of those products that previously came from outside Russia (Adamowski, 2017). While the growth in Russia is expected to continue, it is unclear how future governance decisions might impact the growth of aquaculture.

In Norway, aquaculture licensing and permitting processes can be a hindrance in an uncertain future. Legal requirements limit production sites because a license is granted for one region and cannot be transferred to any of the other four regions in place for aquaculture management. Model predictions show a significant improvement in productivity for the northern farms and vice versa for the farms furthest south and a corresponding northward shift in production if the restrictions are lifted (Hermansen \& Heen, 2012). 


\section{Discussion: Renewable economies, SDGs, and knowledge gaps}

Because renewable economies are so tightly linked with sustainable development, the authors chose to organise the discussion around the UN SDGs (UN 2020). The UN SDGs are a list of 17 priority goals that serve as a call to action for countries around the world, and provide a basis of comparison for tracking the progress of sustainable development (UN, 2020). All SDGs are relevant for Arctic nations; however, it has been noted that the SDGs were not created with the Arctic in mind and certain goals are difficult to scale down (Sköld, Baer, Scheepstra, Latola, \& Biebow, 2018). Specifically, goals related to poverty, food, education, water, and sanitation are not often thought of as important topics in Arctic nations due to a dichotomy in the UN between developing and developed nations, but these issues can have high variance in the Arctic depending on country and region (Kroll et al 2019; Menezes \& Chater, 2018). It has been suggested that the SDGs can be addressed through the development of indicators that are Arctic-specific (Sköld, Baer, Scheepstra, Latola, $\&$ Biebow, 2018). Following this line of thought, the authors of this chapter selected seven SDGs that have the most relevance in identifying knowledge gaps for Arctic fisheries and aquaculture. Based on the information provided in Sections 2 and 3, we identify below 2-3 priority points for each SDG that identify areas of future focus for researchers and decision-makers that will help track indicators and therefore the fulfillment of SDG targets. For ease of dissemination, the following section presents a series of graphics. With each SDG, bullet points are listed to provide recommendations by the authors for priority areas of research questions that would create relevant data to assess the goal under the lens of Arctic fisheries and aquaculture.

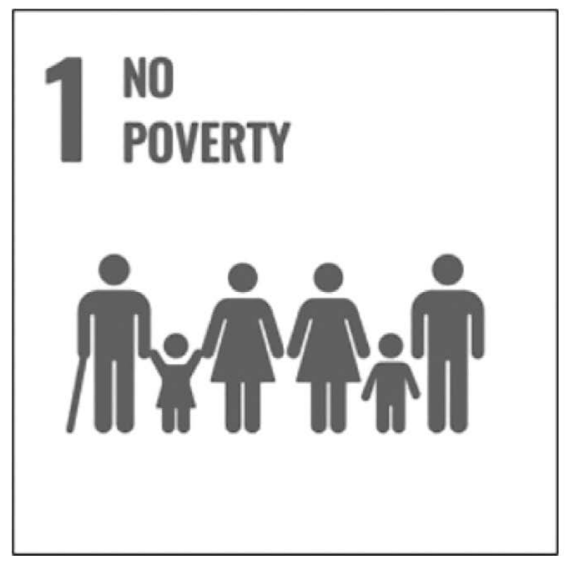

- Model the contribution of Arctic fisheries
and aquaculture to Target 1.2 on reducing
poverty by at least half among men,
women and children by 2030 according to
national definitions.
- Given the sensitivity of the Arctic marine
environment and resource dependency of
remote communities, effort should be
made to gather data on how fisheries and
aquaculture can help to build the resilience
of the poor and those in vulnerable
situations, and reduce their exposure and
vulnerability to climate-related extreme
events and other economic, social and
environmental shocks and disasters.
- Explore potential data gaps in poverty
indicators that are not visible at national or
regional levels.

Figure 12.1 SDG 1 "No Poverty" and related research topics. (SDG image reproduced from https://sdgs.un.org/goals) 


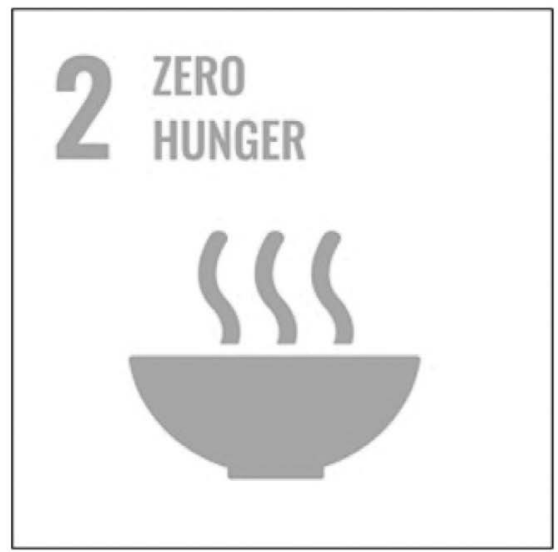

\begin{tabular}{|l|}
\hline - Quantify the extent to which Arctic \\
fisheries and aquaculture can contribute to \\
ending hunger among Arctic communities, \\
in accordance with the objectives of Target \\
2.1. \\
- Assess the extent to which national \\
investment strategies in Arctic nations are \\
targeting the fulfilment of Target 2.A \\
through focus on fisheries and aquaculture. \\
- Gather data on the extent to which \\
developed aquaculture markets in the \\
Arctic, e.g. in Norway (increasingly Iceland), \\
are contributing to the meeting of Target \\
2.C on price stability in commodity markets. \\
\end{tabular}

Figure 12.2 SDG 2 "Zero Hunger" and related research topics. (SDG image reproduced from https://sdgs.un.org/goals)

\section{GOOD HEALTH 3 AND WELL-BEING}

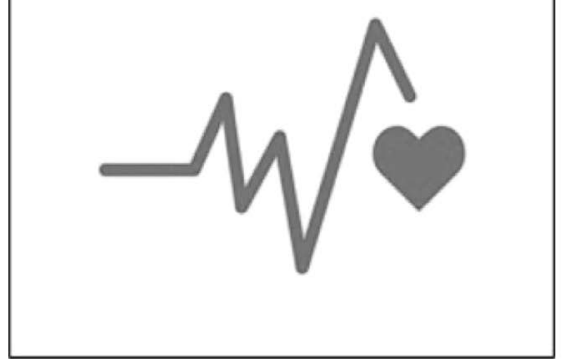

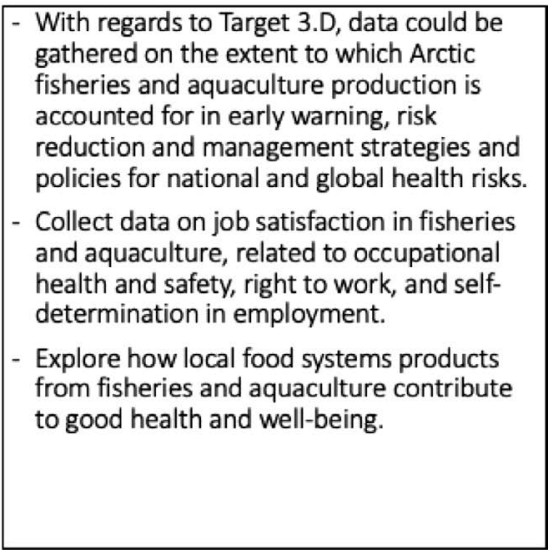

Figure 12.3 SDG 3 "Good Health and Well-being" and related research topics. (SDG image reproduced from https://sdgs.un.org/goals) 


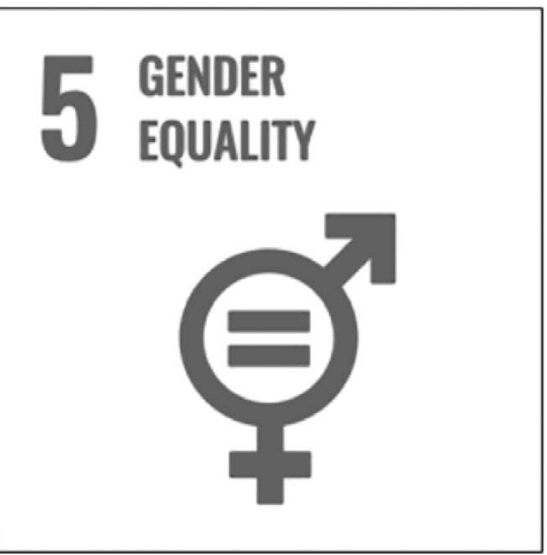

\begin{tabular}{|l|}
\hline - Explore how Target 5.5 is fulfilled in \\
ensuring women's full and effective \\
participation and equal opportunities for \\
leadership at all levels of decision-making \\
in political, economic and public life. \\
- Quantify Target 5.A: "Undertake reforms to \\
give women equal rights to economic \\
resources, as well as access to ownership \\
and control over land and other forms of \\
property, financial services, inheritance and \\
natural resources, in accordance with \\
national laws". \\
- Target 5.C could be considered in the \\
context of the increasing role of technology \\
in fisheries and aquaculture - how to use \\
information and communications \\
technology to promote the empowerment \\
of women. \\
\hline
\end{tabular}

Figure 12.4 SDG 5 "Gender Equality" and related research topics. (SDG image reproduced from https://sdgs.un.org/goals)

\section{DECENT WORK AND ECONOMIC GROWTH}

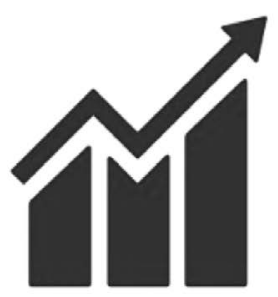

Explore the contribution of fisheries and aquaculture sectors in Arctic nations to sustaining economic growth, in accordance with Target 8.1. Satellite accounts could be used or developed for the sectors, akin to tourism satellite accounts for GDP used in Iceland.

- Specific to Target 8.3 on job creation, this could be assessed with a particular focus on local community job creation and potential economic multiplier effects.

Related to Target 8.4, gather more data on the efficiency of production and consumption in Arctic fisheries and aquaculture, particularly the potential decoupling of the growth of the industry from environmental degradation e.g. economic growth versus GHG emissions or energy consumption. Various economic/ resource intensity measures that already exist could be applied in this context.

Figure 12.5 SDG 8 "Decent Work and Economic Growth" and related research topics. (SDG image reproduced from https://sdgs.un.org/goals) 

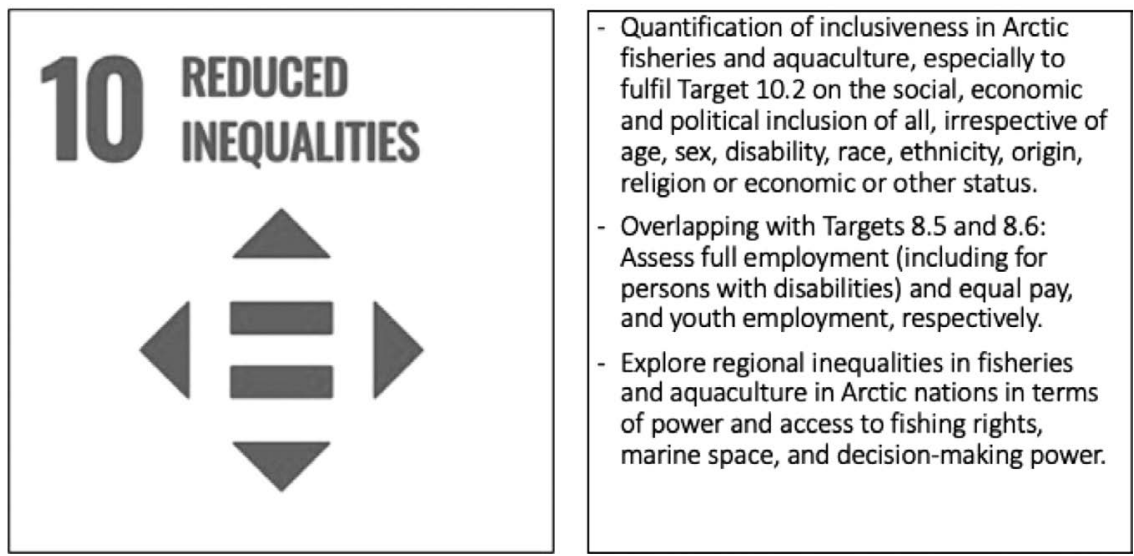

Figure 12.6 SDG 10 "Reduced Inequalities" and related research topics. (SDG image reproduced from https://sdgs.un.org/goals)

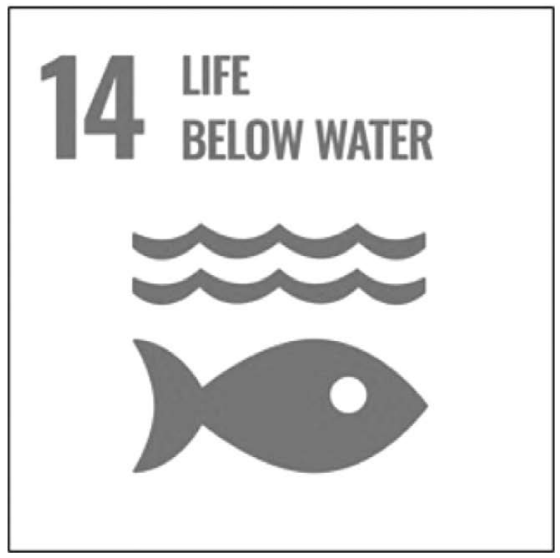

\begin{tabular}{|l|}
\hline - Given the issue of ocean acidification that \\
already affects Arctic coastal communities, \\
data gathering should focus on Target 8.3, \\
looking at the extent to which Arctic \\
fisheries and aquaculture is endeavouring \\
to minimise and address its impacts. \\
- Research could focus on the extent to \\
which there is overfishing and illegal fishing \\
in Arctic waters, as per the requirement of \\
Target 14.4 . \\
- Develop better regional models for \\
temperature increases and storm events \\
that may impact the growth of aquaculture. \\
- Explore how migration of fish stocks could \\
benefit Arctic fishing communities in the \\
short run (like the mackerel in Greenland \\
during the past five years). \\
\hline
\end{tabular}

Figure 12.7 SDG 14 "Life Below Water" and related research topics. (SDG image reproduced from https://sdgs.un.org/goals)

\section{Conclusion}

As reviewed in this chapter, many reports produced for the Arctic Council, among others, have detailed the best available knowledge of Arctic fisheries and aquaculture. The goal of this chapter was to put that knowledge in the context of renewable economies and sustainable development to provide key considerations for Arctic communities and decision makers. The UN SDGs are not a perfect framework to guide policy concerning renewable economies in the Arctic, but instead provide a starting point to build effective future policy and research for renewable, sustainable Arctic fisheries and 
aquaculture. This chapter has reviewed the prevailing social, economic, and climate-related challenges to Arctic fisheries and aquaculture, and provided a path forward by creating recommendations for future focus related to seven SDGs that are most closely related to fisheries and aquaculture: No Poverty (1), Zero Hunger (2), Good Health and Well-being (3), Gender Equality (5), Decent Work and Economic Growth (8), Reduced Inequalities (10), and Life Below Water (14). Through the focus on SDG's, this chapter highlights the need for Arctic-specific data collection and modeling that is not currently clearly visible through larger indicator data sets in fisheries and aquaculture. For example, poverty indicators, hunger elimination national objectives, job satisfaction and well-being data sets, and gender and technology aspects are not often considered with specific focus on fisheries and aquaculture. However, these industries and livelihoods, when practiced renewably and sustainably, may be key factors in fulfilling Arctic-specific SDGs. The path forward to renewable economies in the Arctic related to fisheries and aquaculture must start with better and more detailed Arctic-specific focus related to commercial and subsistence fisheries and aquaculture.

\section{Acknowledgments}

The authors would like to acknowledge funding support from the Arctic Council SDWG for the development of this chapter and the editors for their support. This chapter was also supported in part by financial support from the Nordic Centre of Excellence ARCPATH (Arctic Climate Predictions Pathways to Resilient, Sustainable Communities) (grant number 76654).

\section{References}

Adamowski, J. (2017). Russia to increase salmon aquaculture. The Fish Site. https:// thefishsite.com/articles/russia-to-increase-salmon-aquaculture

ADF\&G. (n.d.) Aquatic farming. Alaska Department of Fish and Game. https:// www.adfg.alaska.gov/index.cfm?adfg=fishingaquaticfarming.main

Agreement to prevent unregulated high seas fisheries in the central Arctic Ocean. (2020). Ministry of Foreign Affairs of Japan. https://www.mofa.go.jp/mofaj/ files/000449233.pdf.

Allison, E. H., Badjeck, M. C., \& Meinhold, K. (2011). The implications of global climate change for Molluscan aquaculture. In S.E. Shumway (Ed.), Shellfish aquaculture and the environment (461-483). Wiley.

Alvarez, J., Yumashev, D., \& Whiteman, G. (2020). A framework for assessing the economic impacts of Arctic change. Ambio, 49(2), 407-418.

AMAP. 2018. AMAP Assessment 2018: Arctic Ocean Acidification. Arctic Monitoring and Assessment Programme (AMAP).

Amundsen, H. 2012. Illusions of resilience? An analysis ofcommunity responses to change in Northern Norway. Ecology and Society 14(4): 46.

AP. (2012). Aquaculture in the Arctic. Arctic Portal. https://arcticportal.org/ yar-features/625-aquaculture-in-the-arctic 
Arnesen, A. M., Jørgensen, E. H., \& Jobling, M. (1993). Feed intake, growth and osmoregulation in Arctic charr, Salvelinus alpinus (1.), following abrupt transfer from freshwater to more saline water. Aquaculture, 114, 327-338.

Ayles, B., Porta, L., \& McV Clarke, R. (2016). Development of an integrated fisheries co-management framework for new and emerging commercial fisheries in the Canadian Beaufort Sea. Marine Policy, 72, 246-254.

Barbier, E. B., \& Burgess, J. C. (2017). The sustainable development goals and the systems approach to sustainability. Economics: The Open-Access, OpenAssessment E-Journal, 11(2017-28), 1-23.

Bittenbender, S. (2019) With environmentalist support, Alaska Rep. Don Young files anti-aquaculture bill. SeafoodSource. https://www.seafoodsource.com/news/ aquaculture/with-environmentalist-support-alaska-rep-don-young-files-anti-aquaculture-bill

Braund, S. R. (2012). Quantification of subsistence and cultural need for bowhead whales by Alaska Eskimos. Prepared for the Alaska Eskimo Whaling Commission, Barrow Alaska. IWC/64/AWS 3 Agenda item 6.1.2. https://iwc.int/ private/downloads/6BOXTFAz3CvHjbIMkcyDMQ/64-ASW\%203.pdf

Bœuf, G., \& Payan, P. (2001). How should salinity influence fish growth? Comparative Biochemistry and Physiology-Part C: Toxicology \& Pharmacology, 130, 411-423.

Bonsell, C., \& Dunton, K. H. (2018). Long-term patterns of benthic irradiance and kelp production in the central Beaufort Sea reveal implications of warming for Arctic inner shelves. Progress in Oceanography, 162, 160-170.

Burrows, M. T., Schoeman, D. S., Buckley, L. B., Moore, P., Poloczanska, E. S., Brander, K. M. ... Holding, J. (2011). The pace of shifting climate in marine and terrestrial ecosystems. Science, 334(6056), 652-655.

CAFF. (2013). Arctic Biodiversity Assessment: Status and trends in Arctic biodiversity. Conservation of Arctic Flora and Fauna, Akureyri.

Chambers, C., Einarsson, N., \& Karlsdóttir, A. (2020). Small-scale fisheries in Iceland: Local voices and global complexities. In C. Pita, J. Pascuel and M. Bavinck (Eds.), Small scale fisheries in Europe. Springer.

Cheung, W. W., Jones, M. C., Reygondeau, G., Stock, C. A., Lam, V. W., \& Frölicher, T. L. (2016). Structural uncertainty in projecting global fisheries catches under climate change. Ecological Modelling, 325, 57-66.

CIESM. (2018). Engaging marine scientists and fishers to share knowledge and perceptions - Early lessons (F. Briant, Ed.). CIESM Publishers. http://www.ciesm. org/online/monographs/download.php?file=exec50.pdf

Craig, P. C. (1984). Fish use of coastal waters of the Alaska Beaufort Sea: A review. Transactions $f$ the American Fisheries Society, 113, 265-282.

Craig, P. C. (1987). Subsistence fisheries at coastal villages in the Alaskan Arctic, 1970-1986. Minerals Management Service.

Craig, P. C. (1989). An introduction to anadromous fishes in the Alaskan Arctic. Biological Paper of the University of Alaska, 24, $27-54$.

Craig, P. C., Griffiths, W. B., Haldorson, L., \& McElderry, H. (1985). Distributional patterns of fishes in an Alaskan Arctic lagoon. Polar Biology, 4, 9-18.

Dutil, J. D., Lambert, Y., \& Boucher, E. (1997). Does higher growth rate in Atlantic cod (Gadus morhua) at low salinity result from lower standard metabolic rate or increased protein digestibility? Canadian Journal of Fisheries and Aquatic Science, 54, 99-103. 
Edsall, T. A. (1999). The growth-temperature relation of juvenile lake whitefish. Transactions of the American Fisheries Society, 128, 962-964.

Elliott, K. H., \& Gaston, A. J. (2008). Mass-length relationships and energy content of fishes and invertebrates delivered to nestling thick-billed Murres Uria lomvia in the Canadian Arctic, 1981-2007. Marine Ornithology, 36, 25-34.

European Commission. (2018). EU and Arctic partners enter historic agreement to prevent unregulated fishing in high seas. European Commission of the European Union. https://ec.europa.eu/fisheries/eu-and-arctic-partners-enter-historic-agreement-prevent-unregulated-fishing-high-seas_en

Executive Order 13921, 85 Federal Register 28, 471. (2020). https://www. federalregister.gov/documents/2020/05/12/2020-10315/promoting-americanseafood-competitiveness-and-economic-growth

Fechhelm, R. G., \& Fissel, D. B. (1988). Recruitment of Canadian Arctic cisco (Coregonus autumnalis) into Alaskan waters. Canadian Journal of Fisheries and Aquatic Science, 45, 906-910.

Fechhelm, R. G., \& Griffiths, W. B. (1990). Effect of wind on the recruitment of Canadian Arctic Cisco (Coregonus autumnalis) into the central Alaskan Beaufort Sea. Canadian Journal of Fisheries and Aquatic Science, 47, 2164-2171.

Fechhelm, R. G., Fitzgerald, P. S., Bryan, J. D., \& Gallaway, B. J. (1993). Effect of salinity and temperature on the growth of yearling Arctic Cisco (Coregonus autumnalis) of the Alaskan Beaufort Sea. Journal of Fish Biology, 43, 463-474.

Fechhelm, R. G., Bryan, J. D., \& Griffiths, W. B. et al. (1994). Effect of coastal winds on the summer dispersal of young Least Cisco (Coregonus sardinella) from the Colville River to Prudhoe Bay, Alaska: A simulation model. Canadian Journal of Fisheries and Aquatic Science, 51, 890-899.

Fechhelm, R. G., Martin, L. R., \& Gallaway, B. J. et al. (1999). Prudhoe Bay causeways and the summer coastal movements of Arctic Cisco and Least Cisco. Arctic, $52,139-151$.

Fechhelm, R. G., Streever, B., \& Gallaway, B. J. (2007). The Arctic Cisco (Coregonus autumnalis) subsistence and commercial fisheries, Colville River, Alaska: A conceptual model. Arctic, 60, 421-429.

Fisheries and Oceans Canada 2020. Aquaculture. Government of Canada. https:// www.dfo-mpo.gc.ca/stats/aquaculture-eng.htm. Accessed 7 July 2020.

Ford, J. D., McDowell, G., \& Pearce, T. (2015). The adaptation challenge in the Arctic. Nature Climate Change, 5(12), 1046-1053.

Fondahl, G., Filippova, V., \& Mack, L. (2015). Indigenous peoples in the new Arctic. In The new Arctic (7-22). Springer.

Fritz, M., Vonk, J. E., \& Lantuit, H. (2017). Collapsing Arctic coastlines. Nature Climate Change, 7(1), 6-7.

Galappaththi, E. K., Ford, J. D., Bennett, E. M., \& Berkes, F. (2019). Climate change and community fisheries in the Arctic: A case study from Pangnirtung, Canada. Journal of Environmental Management, 250, 109534.

Gatt, K. P., Hamman, C. R., Priest, J. T., \& Sutton, T. M. (2019). Beaufort Sea Nearshore Fish Monitoring Study: 2019 Annual Report. Report for Hilcorp Alaska, LLC by the University of Alaska Fairbanks, College of Fisheries and Ocean Sciences, Department of Fisheries, Fairbanks, Alaska

Gibbs, A. E., \& Richmond, B. M. (2015). National assessment of shoreline change historical shoreline change along the North coast of Alaska, U.S.-Canadian border to Icy Cape. U.S. Geological Survey Open-File Report 2015-1048. 
Hansen, E. A., \& Closs, G. P. (2009). Long-term growth and movement in relation to food supply and social status in a stream fish. Behavioral Ecology, 20, $616-623$.

Harter, B. B., Elliott, K. H., Divoky, G. J., \& Davoren, G. K. (2013). Arctic cod (Boreogadus saida) as prey: Fish length-energetics relationships in the Beaufort Sea and Hudson Bay. Arctic, 66, 191-196.

Harvey, F. (2018). Commercial fishing banned across much of the Arctic. The Guardian. https://www.theguardian.com/environment/2018/oct/03/commercialfishing-banned-across-much-of-the-arctic

Hermansen, Ø., \& M. Troell(2012). Aquaculture in the Arctic. A review. Report no. 36, Nofima, Tromsø.

Hermansen, Ø, \& Heen, K. (2012). Norwegian Salmonid farming and global warming: Socioeconomic impacts. Aquaculture Economics and Management, 16, 202-221.

Hoegh-Guldberg, O., Jacob, D., Taylor, M., Bindi, M., Brown, S., Camilloni, I. ... Zhou, G. (2018). Impacts of $1.5^{\circ} \mathrm{C}$ global warming on natural and human systems. In V. Masson-Delmotte, P. Zhai, H.-O. Pörtner, D. Roberts, J. Skea, P.R. Shukla, A. Pirani, W. Moufouma-Okia, C. Péan, R. Pidcock, S. Connors, J.B.R. Matthews, Y. Chen, X. Zhou, M.I. Gomis, E. Lonnoy, T. Maycock, M. Tignor, and T. Waterfield (Eds.), IPCC special report on the impacts of global warming of $1.5^{\circ} \mathrm{C}$ above pre-industrial levels and related global greenhouse gas emission pathways, in the context of strengthening the global response to the threat of climate change, sustainable development, and efforts to eradicate poverty. IPCC.

IPCC. (2014). Climate change 2014 synthesis report. In Team CW, R.K. Pachauri, L. Meyer, and Working groups I, II and III (Eds.), Fifth assessment report of the intergovernmental panel on climate change (1-151). IPCC.

Irrgang, A. M., Lantuit, H., Gordon, R. R., Piskor, A., \& Manson, G. K. (2019). Impacts of past and future coastal changes on the Yukon coast-threats for cultural sites, infrastructure, and travel routes. Arctic Science, 5(2), 107-126.

Irvine, J. R., Macdonald, R. W., \& Brown, R. J., et al. (2009)/ Salmon in the Arctic and how they avoid lethal low temperatures. North Pacific Anadromous Fish Commission Bulletin, 5, 39-50

Jensen, Ø, \& Rottem, S. V. (2010). The politics of security and international law in Norway's Arctic waters. Polar Record, 46(236), 75-83.

Jones, B. M., Arp, C. D., Jorgenson, M. T., Hinkel, K. M., Schmutz, J. A., \& Flint, P. L. (2009). Increase in the rate and uniformity of coastline erosion in Arctic Alaska. Geophysical Research Letters, 36, 1-5.

Kaiser, B. A., Pahl, J., \& Horbel, C. (2018). Arctic ports: Local community development issues. In N. Vestergaard, B. Kaiser, L. Fernandez, J. Nymand Larsen (Eds.), Arctic marine resource governance and development. Springer Polar Sciences.

Kaiser, B. A., Kourantidou, M., \& Fernandez, L. (2018). A case for The commons: The snow crab in the Barents. Journal of Environmental Management, 210, 338-348.

Kokorsch, M., \& Benediktsson, K. (2018). Where have all the people gone? The limits of resilience in coastal communities. Norsk Geografisk Tidsskrift-Norwegian Journal of Geography, 72(2), 97-114.

Kokorsch, M. (2018). Mapping resilience - coastal communities in Iceland (Unpublished doctoral dissertation or master's thesis). [Ph.D. dissertation, University of Iceland]. University of Iceland, Reykjavík, Iceland. 
Kourantidou, M., Kaiser, B., \& Vestergaard, N. (2021). International governance and Arctic fisheries. In A. D. Nuttall \& M. Nuttall (Eds.), Handbook of Arctic politics. Routledge.

Krrivan, V. (2003). Ideal free distributions when resources undergo population dynamics. Theoretical Population Biology, 64, 25-38.

Kroll, C., Warchold, A., \& Pradhan, P. (2019). Sustainable development goals (SDGs): Are we successful in turning trade-offs into synergies? Palgrave Communications, 5(1), 1-11.

Kuhnlein, H. V., \& Receveur, O. (2007). Local cultural animal food contributes high levels of nutrients for Arctic Canadian indigenous adults and children. The Journal of Nutrition, 1110-1114

Kuo, M. A. (2019) The US and China's Arctic ambitions. The Diplomat. https:// thediplomat.com/2019/06/the-us-and-chinas-arctic-ambitions/

Lam, V. W. Y., Cheung, W. W. L., \& Sumaila, U. R. (2014). Marine capture fisheries in the Arctic: Winners or losers under climate change and ocean acidification? Fish and Fisheries, 17(2), 335-357.

Landauer, M., \& Juhola, S. (2019). Loss and damage in the rapidly changing Arctic. Loss and damage from climate change (pp. 425-447). Springer.

Larsen, P. H., Goldsmith, S., Smith, O., Wilson, M. L., Strzepek, K., Chinowsky, P., \& Saylor, B. (2008). Estimating future costs for Alaska public infrastructure at risk from climate change. Global Environmental Change, 18(3), 442-457.

de March, B. G. E. (1989). Salinity tolerance of larval and juvenile broad Whitefish (Coregonus nasus). Canadian Journal of Zoology, 67, 2392-2397.

Meltofte, H. (Ed.). (2013). Arctic Biodiversity Assessment. Status and trends in Arctic biodiversity. Conservation of Arctic Flora and Fauna (CAFF).

Melvin, A. M., Larsen, P., Boehlert, B., Neumann, J. E., Chinowsky, P., Espinet, X., \& Nicolsky, D. J., et al. (2017). Climate change damages to Alaska public infrastructure and the economics of proactive adaptation. Proceedings of the National Academy of Sciences, 114(2), E122-E131.

Menezes, D. R., \& Chater, A. (Eds.). (2018). Proceedings of the Sustainable Development Goals (SDGs) in the Arctic High-Level Dialogue Series, No.1 (Session 1: Arctic Circle Assembly 2017, Reykjavik, Iceland, 14 October 2017). London: Polar Research and Policy Initiative, February 2018.

Moerlein, K. J., \& Carothers, C. (2012). Total environment of change: Impacts of climate change and social transitions on subsistence fisheries in Northwest Alaska. Ecology and Society, 17, 10.

Molenaar, E. J. (2012). Arctic fisheries and international law: Gaps and options to address them. Carbon \& Climate Law Review, 63-77.

Molenaar, E. J. (2013). Arctic Fisheries Management. The Law of the Sea and the Polar Regions (pp. 243-266). Brill Nijhoff.

Monacci, N. M., Cross, J. N., Hurst, T. P., Long, W. C., \& Rossin, A. (2019). Ocean Acidification in Alaska: Chemistry, Clams, Cod, and Crabs. AGUFM, 2019, OS11C-1491.

Monaghan, P. (2008). Early growth conditions, phenotypic development and environmental change. Philosophical Transactions of the Royal Society B: Biological Sciences, 363, 1635-1645.

Moon, K., Blackman, D. A., Adams, V. M., (2019). Expanding the role of social science in conservation through an engagement with philosophy, methodology, and methods. Methods in Ecology and Evolution; 10, 294-302. doi: https://doi. org/10.1111/2041-210X.13126 
Murray, F., Bostock, J., \& Fletcher, D. (2014). Review of recirculation aquaculture system technologies and their commercial application. Report prepared for the Highlands and Islands Enterprise. University of Stirling. http://www.hie. co.uk/common/handlers/download-document.ashx?id=236008c4-f52a-48d99084-54e89e965573

Newell, J. (2004). The Russian far east: A reference guide for conservation and development. Daniel \& Daniel Publishers. http://urbansustainability.snre.umich.edu/ wp-content/uploads/2012/10/Review_Geographical-Journal_Oldfield.pdf

NOAA Fisheries. (2018). U.S. signs agreement to prevent unregulated commercial fishing on the high seas of the Central Arctic Ocean. NOAA. https://www.fisheries. noaa.gov/feature-story/us-signs-agreement-prevent-un regulated-commercialfishing-high-seas-central-arctic

NPFMC. (n.d.). Arctic fishery management. North Pacific Fishery Management Council. https://www.npfmc.org/arctic-fishery-management/

Østhagen, A. (2019). The new geopolitics of the Arctic: Russia, China and the EU. Wilfried Martens Centre for European Studies. https://www.martenscentre.eu/ sites/default/files/publication-files/geopolitics-arctic-russia-china-eu.pdf

Pahl, J., \& Kaiser, B. A. (2018). Arctic Port development. In N. Vestergaard, B. Kaiser, L. Fernandez, J. Nymand Larsen (Eds.), Arctic marine Resource governance and development. Springer Polar Sciences.

Pauly, D., \& Swartz, W. (2007). Marine fish catches in north siberia (Russia, FAO area 18). In D. Zeller and D. Pauly (Eds.), Reconstruction of marine fisheries catches for key countries and regions (1950-2005). Fisheries Centre Research Reports, 15(2).

Pálsson, S. K. (n.d.). Fishernet - DRAFT country report for Greenland. The Stefansson Arctic Institute. https://www.fishernet.is/images/stories/Country_ report_Greenland.pdf

Pan, M., \& Huntington, H. P. (2016). A precautionary approach to fisheries in the central Arctic Ocean: Policy, science, and China. Marine Policy, 63, 153-157.

Pinsky, M. L., Reygondeau, G., Caddell, R., Palacios-Abrantes, J., Spijkers, J., \& Cheung, W. W. L. (2017). Preparing ocean governance for species on the move. Science, 360(80), 1189-1191.

Pring-Ham, C. (2018). Aquatic farming industry status [conference presentation]. Alaska department of fish and game. https://www.adfg.alaska.gov/static/fishing/ PDFs/aquaticfarming/2018_asga_presentation.pdf

Rayfuse, R. (2018). Regulating fisheries in the Central Arctic Ocean: Much ado about nothing?. In N. Vestergaard, B. Kaiser, L. Fernandez, \& J. Nymand Larsen (Eds.), Arctic marine Resource governance and development. Springer Polar Sciences.

Reist, J. D., Wrona, F. J., Prowse, T. D., Power, M., Dempson, J. B., King, J. R., \& Beamish, R. J. (2006). An overview of effects of climate change on selected Arctic freshwater and anadromous fishes. AMBIO, 35, 381-387.

Resneck, J. (2018). Alaska wary of federal push for marine aquaculture. Alaska Public Media. https://www.alaskapublic.org/2018/09/06/alaska-waryof-federal-push-for-marine-aquaculture/

SADA Report. (2014). Strategic Environmental Impact Assessment of Development of the Arctic. https://www.arcticinfo.eu/images/pdf/SADA_report.pdf

Seigle, J. C., \& Gottschalk, J. M. (2013). Fall 2012 subsistence fishery monitoring on the Colville River. ABR, Inc. - Environmental Research \& Services. 
Schatz, V. J., Proelss, A., \& Liu, N. (2019). The 2018 agreement to prevent unregulated high seas fisheries in the Central Arctic Ocean: A critical analysis. International Journal of Marine and Coastal Law, 34, 195-244.

Sköld, P., Baer, K., Scheepstra, A., Latola, K., \& Biebow, N. (2018). The SDGs and the Arctic: The need for polar indicators [Paper presentation]. Arctic Observing Summit 2018, Davos, Switzerland.

Somerville, C., Cohen, M., Pantanella, E., Stankus, A., \& Lovatelli, A. (2014). Smallscale aquaponic food production - Integrated fish and plant farming (FAO Fisheries and Aquaculture Technical Paper No. 589). FAO. www.fao.org/3/ai4021e.pdf

Statistics Greenland. (2019). Greenland in figures 2019. Statistics Greenland. http://www.stat.g1/LinkClick.aspx?link=Intranet\%2fGIF_2009_WEB. pdf $\&$ tabid $=57 \& \mathrm{mid}=473 \&$ language $=$ en - US

Statistics Iceland. (2020). Aquaculture in Iceland. Statistics Iceland. https://www. statice.is/publications/news-archive/fisheries/aquaculture-in-iceland/\#: :text $=$ There $\% 20$ has $\% 20$ been $\% 20 \mathrm{a} \% 20$ significant, has $\% 20$ been $\% 20$ increasing $\% 20$ every $\% 20$ year.

Stephen, K. (2018). Societal impacts of a rapidly changing Arctic. Current climate change reports, 4(3), 223-237.

Streletskiy, D. A., Suter, L. J., Shiklomanov, N. I., Porfiriev, B. N., \& Eliseev, D. O. (2019). Assessment of climate change impacts on buildings, structures and infrastructure in the Russian regions on permafrost. Environmental Research Letters, 14(2), 025003.

Sumaila, R. (2015). Indigenous fisheries in a changing Arctic. News Deeply. https://www.newsdeeply.com/arctic/community/2015/12/08/indigenousfisheries-in-a-changing-arctic

Sumaila, U. R., Lam, V. W. Y., Miller, D. D., Teh, L., Watson, R. A., Zeller, D. ... Pauly, D. (2015). Winners and losers in a world where the high seas is closed to fishing. Scientific Reports, 5, 1-6.

Suter, L., Streletskiy, D., \& Shiklomanov, N. (2019). Assessment of the cost of climate change impacts on critical infrastructure in the circumpolar Arctic. Polar Geography, 42(4), 267-286.

Thorsteinson, L. K., \& Love, M. S. (2016). Alaska Arctic marine fish ecology catalog. U.S. Geological Survey Scientific Investigations Report 2016-5038 (OCS Study, BOEM 2016-048).

Troell, M., Eide, A., Isaksen, J., Hermansen, Ø, \& Crépin, A. S. (2017). Seafood from a changing Arctic. $A M B I O, 46(3), 368-386$.

US Dept of State. (2020). The United States Ratifies Central Arctic Ocean Fisheries Agreement. US Department of State. https://translations.state.gov/2019/08/27/ the-united-states-ratifies-central-arctic-ocean-fisheries-agreement/

Van Pelt, T. I., Huntington, H. P., Romanenko, O. V., \& Mueter, F. J. (2017). The missing middle: Central Arctic Ocean gaps in fishery research and science coordination. Marine Policy, 85, 79-86.

Vilhjalmsson, H., Hoel, A. H., Agnarsson, S., Arnason, R., Carscadden, J. E., Eide, A., ... Wilderbuer, T. (2005). Fisheries and aquaculture. Arctic Climate Impact Report (pp. 691-780). Cambridge University Press.

Walker, D. A., \& Peirce, J. L. (2015). Rapid Arctic Transitions due to Infrastructure and Climate (RATIC): a contribution to ICARP III (Alaska Geobotany Center Publication AGC 15Z 02). University of Alaska Fairbanks. 
Wassmann, P., Duarte, C. M., Agust, S., \& Sejr, M. (2011). Footprints of climate change in the Arctic marine ecosystem. Global Change Biology, 17, 1235-1249.

Zeller, D., Booth, S., Pakhomov, E., Swartz, W., \& Pauly, D. (2011). Arctic fisheries catches in Russia, USA, and Canada: Baselines for neglected ecosystems. Polar Biology, 34, 955-973.

Zhang, Y., Yamamoto-Kawai, M., \& Williams, W. J. (2020). Two decades of Ocean acidification in the surface waters of the Beaufort Gyre, Arctic Ocean: Effects of sea ice melt and retreat from 1997-2016. Geophysical Research Letters, 47(3), e60119. 